Digital Press Social Sciences and Humanities

Society and Taxes: An Exploratory Study of Fiscal

Psychology

Ika Rahma Susilawati and Rahmat Hidayat

Proceeding of The 10th International Conference of Indigenous and Cultural

Psychology 2019

Kwartarini Wahyu Yuniarti, Donald H. Saklofske, Rosnah Ismail, Saadi Lahlou (eds) 


\title{
Society and Taxes: An Exploratory Study of Fiscal Psychology
}

\author{
Ika Rahma Susilawati* \& Rahmat Hidayat \\ 1 Fakultas Psikologi, Universitas Gadjah Mada, Yogyakarta, Indonesia \\ *e-mail: ika.rahma.s@mail.ugm.ac.id
}

\begin{abstract}
This study aims to obtain the social representation of Indonesian society about taxes, especially those originating from the suburban and rural areas. Our previous study reported results that more people are representing those who live in urban areas and have higher digital literacy skills. Therefore, this study was conducted to broaden society's representative. Data was retrieved by direct social interaction to the people who are in public areas like traditional markets, rural areas, terminals, train stations, and small and medium enterprises around the campus area. A total of 121 respondents participated in this study. The analysis reveals the finding of 27 categories in terms of the social representation of tax. Among these categories, the highest frequency of occurrence is in the obligation categorization. Later, followed by categories of public interest, burdens, necessary, and corruption. In general, most respondents associate taxes with obligations. They acknowledge the importance of tax in an ideal, normative, and constitutional way. Under those circumstances, it heads them to comply with the tax rules. This reinforces the reasons why they tend to be more tax- compliant. However, tax is also associated with financial and non-financial burdens. The widespread practice of corruption or misuse of tax money further diminishes people's trust towards the government. This becomes a potential factor in progressively reducing individual tax compliance. A more extensive discussion is presented in the discussion.
\end{abstract}

\section{Keywords}

digital literacy, fiscal psychology, social representation, tax

\section{Introduction}

Psychology contributes to a diverse perspective for acknowledging economic behavior, especially in the context of taxation behavior. In contrast with economics, which is more oriented to macro perspective and meta-theoretical approach. Psychology is emphasized in micro-social approaches especially on individual and social psychological dynamics that underlie the behavior formation in certain contexts and situations (Lewis, 2008). Some researchers suggest a social representation, or frequently known as perception, represents a fundamental aspect to comprehend the formation of beliefs, attitudes, intentions, and behaviors in terms of taxes (Hofmann, Hoelzl, \& Kirchler, 2008; Kirchler, 1999, 2007). In addition, perception influences individual decision-making processes (Bahamonde-Birke, Kunert, Link, \& Ortúzar, 2015).

One of the fiscal psychology models that employ the theory of planned behavior indicates taxpayer conduct is determined directly by intention. Furthermore, willingness to pay taxes represent functions of individual attitudes toward tax behavior, perceived subjective norms, and perceived behavioral control (Fishbein \& Ajzen, 2010). Besides, Lewis (1982, 2008) states studying attitudes help to acknowledge more comprehensively and predict economic behavior. Subsequently, Devos (2014) suggested further studies of tax behavior measured the perceived fairness or justice of the tax system as well as to measure the perceptions of taxpayers comprehensively, also to investigate how these perceptions are formed (Susilawati \& Hidayat, 2019a, 2019b).

However, there has been little discussion and publications of social representations in the taxation context. Notably how these social representations of tax are constructed (Kirchler, 1998; Kirchler \& Maciejovsky, 2001; Schmolders, 1959). Remarkably, in Indonesia, no previous study had been confirmed (Susilawati \& Hidayat, 2019b). Therefore, we conducted research on the social representation of taxes in the Indonesian context. Our previous study has been carried out by an online survey through social media. We conducted this research to reach out to the community representatives, especially the 
laypeople community. Hence, this study aims to get a picture of the social representation of taxation in suburban and rural communities.

Based on our chronological review of the social representation of tax, through psychological reconstruction obtained from the traces of Indonesian history since the kingdom era to present. Taxes consist of four meaningful fundamental representations for Indonesian people. First, in the archipelago's royal period. Taxes were regarded as a forced obligation, collected, and used arbitrarily. Second, in the colonial period. Tax is considered as a form of extortion and colonialism (Onghokham, 1985; Susilawati \& Hidayat, 2019b). Third, in the Indonesian independence period, tax is interpreted as a form of contribution. Moreover, it is associated with a sense of nationalism and the spirit of establishing a country. Fourth, in the Soeharto New Order period, tax is considered as a futile or useless contribution due to the massive movement of unethical behavior of the authorities and state rulers. For instance, acts of corruption, conspiracy, preferential treatment, and other frauds. This last representation still strongly imprinted to Indonesian people even until now. Nowadays, the tax representation of laypeople more influenced by the political and economic conditions of the State (Onghokham, 1985; Susilawati \& Hidayat, 2019b).

Starting from assumptions built through those psychological reconstructions, we executed an initial exploratory study. These investigations conducted to explore various social representations about taxes in our society. Our previous study was conducted on 309 respondents from various regions and demographic characteristics. The result revealed three substantial things. First, by respondent data analysis, consecutively based on the code occurrence frequencies. The result reveals that tax represents neutral or technical, positive, and the lowest remain negative themes. The result is in line with the previous study about the image of the Directorate General of Taxes, trust, and tax compliance intentions. The preliminary study reveals taxpayers predominantly possess neutral to positive perception towards the tax office. Significantly, taxpayers have moderately high scores of trust and compliance intention (Susilawati, Fitriani, Putra, Hidayat, \& Nurdiansyah, 2016).

Secondarily, by words data analysis showed that negative representations of tax emerged more frequently than positives, and neutral-technical themes (Susilawati \& Hidayat, 2019c). This result supports previous studies in Germany and Austria. In Germany, technical associations are the most sizeable percentage, followed by negative and obligation theme (Schmolders, 1959). Whereas in Austria, the first five words that appear as spontaneous responses remain negative. Later followed by neutral and positive themes (Kirchler, 1998).

Lastly, the demographic classifications exhibit differences in dominant representations among several groups, for example, the taxpayer status, educational background, and job classification. Based on the taxpayer status, the taxpayer group maintains more significant negative representations than the nontaxpayer. In addition, based on the academic level, the higher the academic level, the higher frequency of negative representations occurs. Ultimately, by job classification, among several groups of jobs, workers in academic institutions, private workers, entrepreneurs or employers, free-workers, and housewives are groups that gain higher negative representations. In contrast, only the civil servant obtains more significant positive representations and a sense of duty (Susilawati \& Hidayat, 2019c).

The preceding paragraphs explain the social representation of tax in our society utilizing social media and online data gathering. It is assumed that only individuals with higher digital literacy skills are reached. This becomes the limitation of our previous study. Accordingly, this study conducted in person to person interaction with the public who live in the suburban or rural area specifically in the Special Region of Yogyakarta and East Java Province. Therefore, it is expected that the results can be more representative to represent laypeople's social representation of taxation.

\section{Method}

Predominantly, the research respondents participated were Indonesians with the age of over seventeen years old. Descriptively, as much 121 people participated with the characteristics outlined below. First, based on taxpayer status, participants from the taxpayer group were 53.72\% (65 respondents), while the non-taxpayers were $46.28 \%$ (56 respondents). The second category was based on age. Sequentially, most of the responders are in the 30-40 years age group, namely 33.88\% (41 respondents), then $40-50$ years group $24.79 \%$ (30 respondents), followed by the $20-30$ years category, $21,49 \%$ (26 respondents). The remaining 50-60 years are $12.40 \%$ (15 respondents). Meanwhile, both categories of more than 60 years old and under 20 years are under $5 \%$. The third category was based on job classifications. There are nine 
occupational representations. The most considerable number of respondents were entrepreneurs as much as 57.02\% (69 respondents). Then the private institution workers as much $15.70 \%$ (19 respondents). The group of farmers, fishermen, gardeners, and others by $8.26 \%$ (10 respondents). Later, both Small and Medium Enterprises or freelancers in a similar number of $6.61 \%$ (eight respondents). Finally, other job classifications are represented under five percent.

In addition, based on the education level, it shows the most sizeable percentage of respondents is the senior high school or equivalent with the amount of 50,41\% (61 respondents). The undergraduate level equal to 22,31\% (27 respondents). Then, the group of elementary school to junior high school is around $16,53 \%$ (20 respondents). The diploma is 9,09\% (11 respondents). The last category obtained is the master's degree or equivalent which has $1,65 \%$ (two respondents). While based on the income rate, it sequentially shows the most considerable number of participants came from the group of 1.1 million to 5 million rupiahs of $65,29 \%$ (79 respondents). Then, below 1 million rupiahs as much as 28,93\% (35 respondents). The group of 5,1 million to 10 million rupiahs is at 3,31\% (four respondents), next is 15,1 million to 20 million at 1,65\%, and lastly 20,1 million to 50 million at $0,83 \%$ (one respondent). We additionally included a secondary demographic data namely respondent's settlement with the following distribution: the region of Yogyakarta City at 40,50\% (49 respondents); the region of Yogyakarta Regency (Bantul, Gunungkidul, Kulonprogo, Sleman, Wates) with the amount of 34,71\% (42 respondents); the area of Lumajang Regency is 21,49\% (26 respondents); Klaten area at 1,65\% (two respondents); then Solo and Wonosobo each $0,83 \%$ (one respondent) respectively.

This is an exploratory study using a qualitative approach. The data were obtained with an open-ended questionnaire containing the question: "what do you think and feel about tax?". The four research assistants were collecting the data by employing an interpersonal interaction. They go to traditional markets, spaces around the bus station, train station, trade center of small-scale enterprises next to the campus area. Besides, they also attended several occasions like tax socialization events such as the gathering held by the Directorate General of Taxes (DGT) of Yogyakarta region which aims to public health service organizations as well as the community empowerment institution event which engaged in the provision of purified water and sanitation in the rural areas (Pamsimas) of Lumajang districts.

The data were analyzed by descriptive content analysis. It remained an appropriate method of analysis to describe the substantial features of the message content, the characteristics of the communication form, also to conclude the body of the message (Neuendorf, 2002). Referring to Neuendorf (2002), the conclusion process is done inductively, through the stages of the theory and background of its determination followed by steps of conceptualizing variables and conceptual definitions. In this study, data resulted from the open-ended question were extracted by words related to tax associations. Subsequently, by the inter-rater agreement, we established categories to give the name for words that were extracted previously. Briefly, we used the utterance coding scheme in this content analysis (Susilawati \& Hidayat, 2019c).

\section{Result}

Predominantly, the analysis found four fundamental themes covering 27 different categories reflecting laypeople's representation of taxes. In the content analysis process of 121 respondents, 313 codes and 93 categories were obtained in the first level categorization. Subsequently, it was deducted by the words meaning similarities. In the next level categorization, we determined 27 categories from the more stringent deductions process of theme discovery. Further detail of themes and categories are described in the table below. 
Table 1 Categories and theme discoveries of tax representations

\begin{tabular}{|c|c|c|}
\hline Themes & Categories & Number of responses \\
\hline \multirow{13}{*}{$\begin{array}{l}\text { Negative } \\
\text { associations }\end{array}$} & Burdens & 31 \\
\hline & Coercion & 8 \\
\hline & Complexity & 11 \\
\hline & Corruption & 15 \\
\hline & Distrust & 2 \\
\hline & Haram & 1 \\
\hline & Lack of tax & 4 \\
\hline & knowledge & \\
\hline & $\begin{array}{l}\text { Non-compliance } \\
\text { intentions }\end{array}$ & 4 \\
\hline & $\begin{array}{l}\text { Poor service } \\
\text { quality }\end{array}$ & 3 \\
\hline & $\begin{array}{l}\text { Punishment \& } \\
\text { disincentives }\end{array}$ & 4 \\
\hline & Tribute & 1 \\
\hline & Unfairness & 12 \\
\hline \multirow{8}{*}{$\begin{array}{l}\text { Neutral } \\
\text { associations }\end{array}$} & Commonplace & 12 \\
\hline & $\begin{array}{l}\text { Ideal tax } \\
\text { expectations }\end{array}$ & 11 \\
\hline & Obligation & 69 \\
\hline & Reciprocal & 4 \\
\hline & Tax mechanisms & 5 \\
\hline & Tax office & 2 \\
\hline & $\begin{array}{l}\text { Technical terms of } \\
\text { tax }\end{array}$ & 6 \\
\hline & Types of taxes & 3 \\
\hline \multirow{6}{*}{$\begin{array}{l}\text { Positive } \\
\text { associations }\end{array}$} & Compliance & 11 \\
\hline & Contributions & 4 \\
\hline & Necessary & 17 \\
\hline & Public interest & 59 \\
\hline & Sense of pride & 2 \\
\hline & Zakat & 2 \\
\hline \multirow{2}{*}{$\begin{array}{l}\text { Non-categorized } \\
\text { associations } \\
\text { Total responses }\end{array}$} & Non-categorized & 7 \\
\hline & & 313 \\
\hline
\end{tabular}

\subsection{First Theme: Negative Associations}

In this theme, there are 13 essential categories representing people's views of taxes. These categories include burden, coercion, complexity, distrust, haram, lack of tax knowledge, misappropriations, noncompliance intentions, poor service quality, punishment, and disincentives, tribute. Generally, the number of tax associations in the negative theme was $30,67 \%$ ( 96 of 313 codes).

1) Burden

Hither represent some examples of participant responses related to tax. In this case, tax as a burden both financially and non-financially.

Making it difficult, predominantly recently, with sluggish economy (the purchasing of gold shop has decrease and the dollar goes up). However, we had to pay taxes. There are too many local levies besides taxes. For example, for waste management cost in the market, etc. .....(p.10)

Shocked, burdening, towards the negative. Taxes represent a burden because my income is uncertain. Therefore, if anything in the market is taxable. It will be a burden for us. ......(p.11)

Very burdensome. The tax burdens the lower income communities. .....(p.47)

Even for those whose income is above 500 million rupiah. A third of their income will be taken. Taken a third from their hard work. .....(p.73) 


\section{2) Coercion}

In this category, tax is considered as coercion. So, it produces negative impressions on the taxpayer of the tax itself. Taxes are assessed as something coercive and binding, shown through the following excerpts..

But some types of taxes are too forced and I feel my rights are taken away. .....(p.73)

Already regulated by law. It seems to force. .....(p.95)

Tax is coercive. .....(p.114)

3) Complexity

Taxes are considered as complicated, long-winded, difficult to learn, and understand. Therefore, it caused confusion and resentment for participants who have tax experience. Some examples of words that represent this are presented at the end.

The tax rules are inevitably altering, which sometimes without any clear socialization. So we don't know about that. As a layman, taxes are quite complicated. .....(p.81)

Dizzy in calculations. .....(p.87)

The payment is complicated......(p.110)

4) Criticism to government

Some participants associate taxes with various expressions of frustration with the government, such as the feeling of disappointment due to lack of reciprocity commensurate with the tax they pay. Criticism is expressed both in terms of corruption, the government's decision in debt (increasing the burden on citizens), and no significant progress of the nation. This is reflected in the statements below.

The government now tends to build too much (the infrastructure), but the money consumed from the state debt. So, tax is impressed to repay the debt. Taxes are heralded and always be oppressed despite we have paid the tax. .....(p.14)

It makes people upset, when they hear the word of tax, they had tried to pay taxes but is being corrupted and the punishment of corruptors does not deter. It makes us demotivated to pay taxes. ... (p.64)

but the government is many tyrannized people. As it happens, tax is not the responsibility of the society, but the responsibility of the government, because the tax is used to pay the state debt (where the government decides to owe). ..... (p.70)

Almost everything is taxed. But there is no national development. ...(p.73)

5) Haram

The view of tax related to the religious point of view is regarded in the statement below. Participants see tax as an unlawful thing because it is coercive and burdensome for subject people to the obligation to pay taxes.

Haram. According to religion, tax is haram because it is forced (if you do not pay, then subject to sanctions). It burdened the society. .....(p.70)

6) Lack of tax knowledge

The lack of tax knowledge category is reflected in the views of some participants who assess their tax knowledge is relatively low, particularly related to tax functions, tax types, and technical information about taxation. Examples are illustrated underneath.

Don't know what the tax is for. Especially the benefits of tax. .....(p.27) 
Many people, however, do not understand the function of tax. .....(p.52)

Lack of socialization and limited public knowledge of the tax type, both become the triggers for confusion of the tax calculations. .....(p.83)

\section{7) Corruption}

Some participants link taxes with misappropriation, especially corruption. Exposing information or news about the disclosure of various major corruption cases in Indonesia, the familiar name of the corruptor influences the public's view that paying taxes is a disadvantage because it is irresponsibly consumed for individual interest.

At present, many taxes are corrupted by the government. So that the tax returns from the people, do not return to the people anymore. .....(p.5)

Unless some individuals are corrupt or misuse tax money for personal interest....(p.63)

It makes people upset, when they hear the word of tax, they had tried to pay taxes but is being corrupted and the punishment of corruptors does not deter. It makes us demotivated to pay taxes. ... (p.64)

There are, nevertheless, many misused of tax funds that appear in various news. .....(p.91)

Gayus tambunan.....(p.98)

Tax money is prone to corrupt. For example, the vehicle tax and the administration cost of vehicle mutation. .... (p.104)

8) Non-compliance intentions

Negative thoughts and attitude toward tax have an impact on increasing non-compliance intentions. This is reflected in several examples of the statements below. The intentions of non-compliance can be recognized from the expression of words like demotivated to pay taxes and tax avoidance.

People may be reluctant to pay taxes because the authorities are misuse and corrupt it.....(p.14)

It makes people upset, when they hear the word of tax, they had tried to pay taxes but is being corrupted and the punishment of corruptors does not deter. It makes us demotivated to pay taxes. ... (p.64)

In fact, they want to obey the tax rules and paying taxes. Unfortunately, the government acts arbitrarily. So, it is better to obey the religion rules than tax rules. .....(p.70)

9) Poor service quality

Few participants associate tax with the tax services they receive. Including issues of waiting in line, hospitality in service, duration of the filling process, etc.

Tax service system is still poor (longlines, the unfriendly officers). .....(p.23)

But, the tax registration and the administration take much time .....(p.26)

The payment and registration services are still complicated and too much takes time. ..... (p.72)

10) Punishment and Disincentives

We found four participants associate taxes with punishment and disincentives as the mechanism to regulate taxpaying behavior. The statement is presented below.

If you are late to pay the tax, you will be penalized. Presently, twice we pay late, the motorcycle can't be used......(p.74) 
Fines. ..... (p.79)

Sanctions. Pay on time. .... (p.86)

11) Tribute

One participant associates tax with tribute. This is a form of tax in kingdom periods.

Tribute. ..... (p.79)

12) Unfairness

Some participants declare tax as an unjust act. Unfair is felt both in terms of the amount of the tariff collected, the proportionality of taxes with income (people's economic capacity), and the perceived direct benefits from the tax paid.

For MSMEs, the current regulation (0,5\% of turnover) is unfair. More agree with the previous regulation. There are certain income restrictions that are only required to pay taxes. .....(p.14)

Disagree. Payment of taxes must be divided based on the level of the people's economy. Tax must redistribute to civils, be uncorrupted. .....(p.22)

The tax is used for construction and public facilities. However, sometimes it does not redistribute to the people. For example: payment of traditional market levies which is collected every day, but the broken lamps never repaired. Then, the toilet is additionally charged, even though people the market trader have already paid the retribution (Kranggan Market). ...(p.24)

Inconsistent. For instance, the road constructions and repairment only prior in town, even though it still in good conditions. Conversely, the road in the countryside unrepair though it urgently need to be repair. We must reexamine the use of tax money.... (p.42)

\subsection{Second Theme: Neutral Associations}

The neutral theme includes tax associations on technical terms and do not describe likes or dislikes emotions. Categories contained $\mathrm{n}$ this theme are commonplace, ideal tax expectations, obligations, reciprocal, tax mechanisms, tax offices, technical terms of tax, and types of taxes. Predominantly, the number of tax associations in the neutral theme was 35,46\% (111 of 313 codes).

13) Commonplace

A total of 12 participants consider the tax as a reasonable thing. Some expressions show tax as a normal thing, has become a habit, there are no problems with paying tax, and something that should be unquestioned. Some of the statements are recorded underneath.

Ordinary. Tax is normal or common in the society. If you want to establish a business, then you must have a Tax Identification Number (TIN). .....(p.36)

Common...paying tax is a common thing. .....(p.55)

It does not have to be a problem. If you do not pay taxes, the price of goods even be more expensive. .....(p.65)

The word of tax in my mind is ordinary, because I know it even since in the fifth grade of elementary school. .....(p.108)

14) Ideal tax expectations

The category illustrates various ideal expectations of participants regarding the performance and function of tax for the state and society. This includes the hope that the 
application of taxes adheres to the principles of justice, simplicity, educative, transparency, and integrity.

My expectations are that taxes should be adjusted in terms of people's ability to pay, not be generalized. .....(p.2)

If possible, make payment process easier. For example, add more payment counters. ..... $(p / 41)$

Nonetheless, many people who do not understand the function of taxation. So, the related governmental institution must increase the socialization to the public....(p.52)

Can be accounted for. In other words, transparent and trustworthy. In that circumstances, people do not mind paying taxes. ...(p.66)

Hopefully, the tax paid by citizens can be used for the welfare of all the citizens. Not abused by the holders of power. .....(p.88)

\section{5) Obligation}

The obligation category describes participants' point of view in terms of tax as a duty, either in reporting, paying, and complying with tax regulations. They also deemed tax as an expression of their sense of responsibility and obligation as Indonesian citizens. Some statements regarding obligations include:

Taxes must be paid. .....(p.3)

Required. Obligations as a citizen. .....(p.12)

Tax is citizen's responsibility. .....(p.29)

...is a government regulation that must be obeyed. .....(p.37)

Mandatory pay, mandatory report .....(p.76)

16) Reciprocal

The reciprocal describes the nature of taxes, in which taxes are collected from the individuals, managed, and returned to the people in diverse forms. Tax can be receiving in the form of infrastructure development, public facilities, education, environmental cleanliness, and others. This is reflected in the statements below.

The tax payment supposed to be redistributed to civils. .....(p.7)

There must be reciprocity, for instance: if you want a pleasant and clean environment, you must pay taxes...(p.38)

17) Tax mechanisms

The taxation mechanism describes the characteristics of a tax time-limited and protected by state law or regulation. The two statements below represent this explanation.

$$
\begin{aligned}
& \text { order, new rules. .....(p.82) } \\
& \text { sanctions; pay on time .....(p.86) }
\end{aligned}
$$

18) Tax office

The tax office represents the neutral representation of taxes. The tax office as a place to report, pay, and information service centers related to taxation.

Tax office, DGT Regional office .....(p.82)

19) Technical terms of tax

This category represents technical terms of taxation. For example, the term "count, Agent Representatives (AR), NPWP (The Identification Tax Number), zero, non-taxed worker (PTKP), certificate of withholding tax, tax amnesty, tariff". 
20) Types of tax

This category facilitates participant responses about taxes related to the types of taxes that exist or apply. Existing statements in between: "central tax, local tax, Income Tax (PPh 21), Land and Property Tax (PBB), Business Permit Tax.".

\subsection{Third Theme: Positive Associations}

The positive theme covers tax associations with beneficial things and supports the existence of taxes. Categories covered in this theme like compliance, contributions, necessary, public interest, sense of pride, and zakat. Total tax associations in positive themes amounted to 30,35\% (95 of 313 codes).

21) Compliance

The compliance category represents a variety of participant responses that indicate actions supporting or carrying out tax activities according to the rules. More specific examples of statements recognized in the quotation below.

Even I do not have money, I always pay tax when due date. .....(p.55)

I consistently pay tax on time. .....(p.60)

I'm happy and obey the rules in paying tax. .....(p.104)

Let's obey the tax rules.....(p.105)

22) Contributions

Some participants interpret paying taxes as proof of the community's contributions to the government. This is reflected in several statements as listed at the end.

People pay taxes to the government as proof of people's trust in the government. I am habitually in controlled manner to pay taxes. ......(p.69)

I'm happy because I could contribute to the nation. .....(p.80)

Participation form in national development .....(p.110)

23) Necessary

Some dominant words that represent the necessary category are important, needed, and good. Some of them emphasized agreeing on the preference of tax because it was expected by the society itself. Some statements regarded underneath

Tax is necessary. .....(p.1)

Agree with the tax, because it is employed to finance the government and national development. .....(p. 6)

Important. .....(p.35)

Good......(p.40)

24) Public interest

This category reflects the tax function as a way to provide national facilities. Most participants realized the importance of taxes for various priorities of society and the state. These concerns include infrastructure development, financing the civil servant's salaries, repaying the country's debt, health insurance. As well as providing and maintaining public facilities, also other public interests.

Taxes are return to us for development, the civil servant's salary, etc. Tax for development. I am always pay tax orderly.....(p.1)

The tax is used for the benefit of the country. So, it must be paid. ......(p.35)

The tax is used to build and also maintain the public facilities.....(p.41) 
Now, in tourist villages, the road is passable and in quite good conditions.

One of the benefits of tax is used for that reason. .....(p.75)

25) Sense of Pride

This category represents a sense of pride or proudness when participants as citizens can contribute to the country, specifically by paying taxes. Two statements represent this category is provided at the end.

I'm happy because I could contribute to the nation. .....(p.80)

I'm proud as a citizen who can afford to pay taxes. .....(p.122)

26) Zakat

Some participants associate taxes with religious views, especially in Islam. Taxes are thought similarly to zakat, so paying taxes is considered a civic virtue.

Obedient because of in religion, there is also zakat.....(p.80)

In Islamic, it similar with zakat maal - zakat fitrah.....(p.105)

\subsection{Fourth Theme: Non-categorized Associations}

The non-categorized association remains a theme to overshadow unincluded tax representations in the three core themes. Categories included pay, money, ownership rights, and easier tax activities are 2,24\% (seven of 313 codes).

Tax is used as a symbol of a property ownership. So, if you do not pay taxes. There is no possession right. .....(p.17)

Pay. .....(p.19,79,88)
Money. .....(p.79)

Nowadays, tax reporting is even easier, by online. .....(p.90)

Based on the results of qualitative data analysis, the social representation of taxes which produces the highest frequency of occurrence is 'obligation' that is 22,04\% (69 out of 313 responses). Then followed by 'public interest' at 18,85\% (59 of 313 responses) and 'burdens' of 9,9\% (31 of 313 responses). The fourth and fifth ranks are filled by 'the necessary' category of 5,43\% (17 of 313 responses), and 'corruptions' of $4,79 \%$ (15 of 313 responses). The following position is equally balanced by 'unfairness' and 'commonplace' each at 3,83\% (12 of 313 responses). Followed by 'compliance', 'ideal tax expectations', and 'complexity' with the equivalent amount of 3,51\% (11 of 313 responses).

\section{Discussion}

The data shows that in rural or suburban communities, the majority of respondents interpreted taxes as an obligation, one thing that becomes a duty and responsibility that must be shouldered as part of Indonesian citizens. This is based on the respondent's subjective meaning that taxes possess a usefulness function for the community welfare itself. Principally, they consider tax is required, and what has been paid will be returned in various forms. Therefore, they considered tax obligations were normal and reasonable to do. These thoughts and beliefs direct individuals to behave in tax compliance.

Therefore, based on the explanation above, we could utilize opportunities to empower the basic of positive representations toward tax. An exposure of effective words represents taxes could benefits the DGT. For instance, through effective advertising campaigns, the proper representations of tax help to provide the accurate message content to be framed. Consequently, it benefits to develop strategies to improve positive attitude and beliefs toward taxes. Finally, increasing tax compliance behavior. Likewise the statement of Karakostas and Zizzo (2016). Sense of duty and social pressure hierarchically by the authorities, can be used as a strategy to increase taxpaying behavior through public advertisements. 
Further, Karakostas and Zizzo (2016) state that obedience norms could improve tax compliance. So it could be suggested in the policy-making, particularly in terms of socialization or advertising campaigns. Karakostas and Zizzo (2016) emphasizes the importance of compliance toward authorities in the model of vertical hierarchical relations or in public policy. Their findings also highlight that $30 \%$ to $40 \%$ of subjects were resistant to the authorities. As a result, they suggested diverse types of interventions to reach one-third of the other taxpayer segmentation.

In cross-cultural psychology perspective, Indonesian tend to be collectivist (Mangundjaya, 2013; Murphy-Berman \& Berman, 2007). Therefore, the emphasis of values like togetherness, sacrifice, and social harmonization enhance critical aspect to strengthen the public's positive sentiment toward taxes. In addition, Hofstede stated that Indonesia represented a country with high power distance. Individuals from high power distance culture tend to behave obediently in terms of fear of authority or resolve disagreement with authorities (Bochner \& Hesketh, 1994). Collectivist societies tend to expect models of paternal or autocratic decision making. Accordingly, in the Indonesian society, the obligation could be directed to the meaning of compliance or obedience toward the authorities. It is assumed that by framing tax with the concept of a compulsory and binding obligation, could strength the intrinsic motivation of individuals to comply with regulations or authorities.

In contrast, the number of levies and the numerous types of taxes that must be paid, subjectively overvalued. Hence, they burden financially for the public. In this research, the majority respondents occupy a middle to more limited income. With the existing economic conditions, spending priorities are to meet basic life needs. Therefore, levies in various forms in life seem increasingly burdensome. Examples are vehicle tax, house and building tax, consumption or purchase tax, and various others that mostly subject components to tax. As shown in the demographic data, specifically, the level of income, most participants came from the earnings group of 1,1 million to five million, amounting to 65,29\% (79 respondents). Followed by groups with below one million income levels of 28,93\% (35 respondents). Other groups that possess earnings above five million only around $5 \%$ of respondents.

Moreover, other factors like the complexity of taxation rules and reporting procedures to finance taxes perceived as non-financial burden. The results showed the complexity of the tax bureaucracy can reduce tax compliance (Picur \& Riahi-Belkaoui, 2006). Based on the age classification, the majority take place groups of 30 years and over, with percentage of more than $70 \%$. In addition, the research sample was people living in rural and suburban areas. Besides, in terms of academic level, around $67 \%$ of respondents receive a maximum education namely high school or equivalent. All three demographic aspects contribute to the lack of knowledge about taxation and economic policy. As several research results show that tax knowledge can improve compliance (Groenland \& Van Veldhoven, 1983; Kirchler, 2007; Kirchler, Maciejovsky, \& Schneider, 2001; Niemirowski \& Wearing, 2003). Conversely, the lack of knowledge and miss-understanding will lead to distrust (Kirchler, 2007). As well as McKerchar (2001) state that individuals frequently blame the complexity of the tax system for their perceived of tax incompetence and the decline of tax interest.

Besides, rampant corruption by government officials who misuse tax money hurt public trust. Corruption arises in the respondent's free association of tax. This is undenied because of the various cases of fraud not merely in DGT, but also in other government institutions. Like the Indonesian proverb "karena nila setitik, rusak susu sebelanga". Similar with "one scabbed sheep is enough to spoil a flock" which means that one significant case of tax evasion caused intense distrust of the public. For instance, Gayus Tambunan as a person of tax misuse is strongly attached to some part of Indonesian. In line with Rosid, Evans, dan Tran-Nam (2017) statement that corruption affects tax compliance. Strengthened the results of Picur dan Riahi-Belkaoui (2006) research that controlling corruption is positively correlated with tax compliance.

Furthermore, the perceived of injustice or unfairness, especially in terms of direct benefits of tax returns and lack of transparency in the tax uses. Fairness category is one of the most frequent topics of social representations of tax (Kirchler, 2007). Likewise, Schmölders (2006) stated perceived of unfairness due to either treatment relate to others or relative to the benefits of public goods are related to tax morale. The unbalanced exchange relationship between the taxpayer and the government breeds distrust and disappointment to the taxpayer. Consequently, it lowered tax compliance. Simultaneously, these negative things (high rate of tax and too many taxes, burden, tax complexity, corruptions) potentially contribute to weaken the intention of taxpaying compliance.

In facts, the DGT has carried out various efforts, especially through mass communication media. In addition, formal and informal events, below the line strategies, also tax slogan socialization. The tax slogan was framed related to the concept of nationalism. Besides, concept of wisdom, national growth and 
development, etc. Woefully, empirical studies unconducted to investigate the effectiveness of the communication strategies that have been applied toward tax awareness and tax compliance of its society.

\section{Conclusion}

The findings reported here shed new light on the research of tax behavior, specifically in cognitive and social psychology perspectives. We underline some substantial information that is the subject of discussion in the context of social representations of taxes. First, individuals have the same probabilities to experience cognitive dissonance conditions (Cooper, 2007; Festinger, 1957; Susilawati \& Hidayat, $2019 \mathrm{~b}$ ). In the context of taxes, individuals use various knowledge and experiences to interpret taxes in different ways, either in informative or technical terms, positive or even negative perspectives.

Secondly, from both studies, there was a high percentage that linked taxes with positive representations, such as compliance, contributions, necessary, public interest, sense of pride and zakat. Similarly, tax representation as a form of obligation. The positive representations as the capital or foundations to increase tax compliance. Nonetheless, it has not been used optimally to improve tax awareness. In addition, positive and obligation theme as the tax representations could be two mainly domain focused on subsequent research. Accordingly, an experimental approach is required to verify the effectiveness of positive and obligation themes in increasing tax awareness and tax compliance through the right communication strategies.

Cognitive and social psychology approaches are fundamentally important to understand the dynamics of behavioral acts based on cognitive process and social norms. Especially in understanding the formation of cognitive dissonance and subjective views or cognitive representations to represent an object in terms of taxation (Kahneman \& Tversky, 2017; Lewis, 2008; McCaffery \& Baron, 2003). Furthermore, how individual subjective views become a determinant factor in the form of values, attitudes, and behavior related to taxation and public policy (Baron \& Maxwell, 1996; Kemp, 2003; Kirchler, 2007; Moscovici, Jovchelovitch, \& Wagoner, 2001).

In addition, a limitation of this study is that the sum of the respondent has been used still limited to represented Indonesian society. It is limited in the area of Yogyakarta and certain districts of East Java. Other limitations lie in the fact that this analysis could be developed comprehensively to construct the conceptual model of tax compliance behavior. By those limitations, it is assumed that several questions, however, remain to be answered. Further work needs to be done to expand the broader range of society for the broader generalizations. Then, modeling work will have to be conducted in order to construct the conceptual framework of tax compliance based on individual representations. Also, further studies need to be held using experimental design to verify the associative strength among various tax representations.

\section{References}

Bahamonde-Birke, J., F., Kunert, U., Link, H., \& Ortúzar, J. D. D. (2015). About attitudes and perceptions finding the proper way to consider latent variables in discrete choice models. German Institute for Economic Research.

Baron, J., \& Maxwell, N. P. (1996). Cost of public goods affects willingness to pay for them. Journal of Behavioral Decision Making, 9, 173-183.

Bochner, S., \& Hesketh, B. (1994). Power distance, individualism/collectivism, and job-related attitudes in a culturally diverse work group. Journal of Cross-Cultural Psychology, 25(2), 233-257. https://doi.org/10.1177/0022022194252005

Cooper, J. (2007). Cognitive Dissonance: 50 years of a classic theory. London: Sage Publications.

Festinger, L. (1957). A Theory Cognitive Dissonance. California: Stanford University Press. 
Fishbein, M., \& Ajzen, I. (2010). Predicting and changing behavior: The reasoned action approach. New York: Psychology Press, Taylor \& Francis Group.

Groenland, E. A. ., \& Van Veldhoven, G. (1983). Tax evasion behavior: a psychological framework. Journal of Economic Psychology, 3, 129-144.

Hofmann, E., Hoelzl, E., \& Kirchler, E. (2008). Preconditions of voluntary tax compliance. Zeitschrift Für Psychologie / Journal of Psychology, 216(4), 209-217. https://doi.org/10.1027/0044-3409.216.4.209

Kahneman, D., \& Tversky, A. (2017). Choices, values, and frames, 830.

Karakostas, A., \& Zizzo, D. J. (2016). Compliance and the power of authority. Journal of Economic Behavior and Organization, 124, 67-80. https://doi.org/10.1016/j.jebo.2015.09.016

Kemp, S. (2003). The effect of providing misleading cost information on the perceived value of government services. Journal of Economic Psychology, 24, 117-128.

Kirchler, E. (1998). Differential Representations of Taxes : Analysis of Free Associations and Judgments of Five Employment Groups. Journal of Socio-Economics, 27(1), 117-131.

Kirchler, E. (1999). Reactance to taxation : Employers' attitudes towards taxes. Journal of Socio-Economics, $28,131-138$.

Kirchler, E. (2007). The Economic Psychology of Tax Behaviour. Cambridge: Cambridge University Press.

Kirchler, E., \& Maciejovsky, B. (2001). Tax compliance within the context of gain and loss situations , expected and current asset position, and profession. Journal of Economic Psychology, 22, 173-194.

Kirchler, E., Maciejovsky, B., \& Schneider, F. (2001). Everyday representations of tax avoidance , tax evasion, and tax flight: Do legal differences matter? Journal of Economic Psychology, 24(4), 535-553. https://doi.org/10.1016/S0167-4870(02)00164-2

Lewis, A. (1982). The social psychology of taxation. British Journal of Oscial Psychology, 21, 151-158.

Lewis, A. (2008). Psychology and economic behaviour. Cambridge: Cambridge University Press.

Mangundjaya, W. L. (2013). Is There Cultural Change In The National Cultures Of Indonesia? International Association for Cross-Cultural Psychology, 59-68. Retrieved from $\mathrm{http} / /$ iaccp.org/drupal/sites/default/files/melbourne_pdf/Melbourne Proceedings.pdf\#page=59

McCaffery, E. J., \& Baron, J. (2003). The humpty dumpty blues: Disaggregation bias in the evaluation of tax systems. Organizational Behavior and Human Decision Processes, 91, 230-242. https://doi.org/10.2139/ssrn.298648

McKerchar, M. (2001). The study of income tax complexity and unintentional noncompliance: Research method and preliminary findings. ATAX Discussion Paper.

Moscovici, S., Jovchelovitch, S., \& Wagoner, B. (2001). Development as a Social Process: Contributions of Gerard Duveen. London: Routledge, Taylor \& Francis Group.

Murphy-Berman, V., \& Berman, J. J. (2007). Cross-Cultural Differences in Perceptions of Distributive Justice. Journal of Cross-Cultural Psychology, 33(2), 157-170. https://doi.org/10.1177/0022022102033002003

Neuendorf, K. A. (2002). The Content Analysis Guidebook. (Margaret H. Seawell, Ed.). California: Sage Publications. 
Niemirowski, P., \& Wearing, A. (2003). Taxation agents and taxpayer compliance. Journal of Australian Taxation, 6, 132-165.

Onghokham. (1985). Pajak dalam perspektif sejarah. Jakarta: Prisma empat.

Picur, R. D., \& Riahi-Belkaoui, A. (2006). The impact of bureaucracy, corruption and tax compliance. Review of Accounting and Finance, 5(2), 174-180. https://doi.org/10.1108/14757700610668985

Rosid, A., Evans, C., \& Tran-Nam, B. (2017). Perceptions of Corruption and Tax Non-compliance Behaviour: Policy Implications for Developing Countries. Bulletin of Indonesian Economic Studies, 0(0), 1-44. https://doi.org/10.1080/00074918.2017.1364349

Schmolders, G. (1959). Fiscal Psychology: A New Branch of Public Finance. National Tax Journal, 15, 184193.

Schmölders, G. (2006). Psychology of Taxation and Public Finance. In The Psychology of money and public finance, 12, pp. 157-210. London: Palgrave Macmillan. https://doi.org/10.1057/9780230625112

Susilawati, I. R., Fitriani, A., Putra, R. P., Hidayat, R. N., \& Nurdiansyah, A. W. (2016). Citra Direktorat Jenderal Pajak (DJP), trust Wajib Pajak, dan intensi kepatuhan pajak. In Temu Ilmiah Nasional Himpunan Psikologi Indonesia. Yogyakarta.

Susilawati, I. R., \& Hidayat, R. (2019a). Dilema sosial : Representasi sosial tentang pajak pada Aparatur Sipil Negara. Jurnal Psikologi Sosial, 17(02), 65-74. https://doi.org/10.7454/jps.2019.10

Susilawati, I. R., \& Hidayat, R. (2019b). Social Representation of tax : Psychological reconstruction of the Indonesian history of tax. In The 13th Biennial Asian Association of Social Psychology Conference. Taipei, Taiwan.

Susilawati, I. R., \& Hidayat, R. (2019c). Tax in the mind of the citizens: A social representation of tax. In Brawijaya International Conference on Social and Political Science (p. 8). Malang, Indonesia. 